\title{
The Neuroimmunology of Chronic Pain: From Rodents to Humans
}

\author{
${ }^{\circledR}$ Peter M. Grace, ${ }^{1}{ }^{\circledR}$ Vivianne L. Tawfik, ${ }^{2}{ }^{\circledR}$ Camilla I. Svensson, ${ }^{3}{ }^{\circledR}$ Michael D. Burton, ${ }^{4}{ }^{\circledR}$ Marco L. Loggia, ${ }^{5}$ and \\ (D) Mark R. Hutchinson ${ }^{6}$ \\ ${ }^{1}$ Laboratories of Neuroimmunology, Department of Symptom Research, University of Texas M. D. Anderson Cancer Center, Houston, Texas 77030, \\ ${ }^{2}$ Department of Anesthesiology, Perioperative, and Pain Medicine, Stanford University School of Medicine, Stanford, California $94305,{ }^{3}$ Department \\ of Physiology and Pharmacology, Karolinska Institutet, Stockholm, Sweden 171 77, ${ }^{4}$ Neuroimmunology and Behavior Laboratory, School of \\ Behavioral and Brain Sciences, Center for Advanced Pain Studies, University of Texas at Dallas, Richardson, Texas 75080, ${ }^{5}$ Athinoula A. Martinos \\ Center for Biomedical Imaging, Department of Radiology, Massachusetts General Hospital, Harvard Medical School, Boston, Massachusetts 02129, \\ and ${ }^{6}$ Australian Research Council Centre of Excellence for Nanoscale BioPhotonics and Adelaide Medical School, University of Adelaide, Adelaide, \\ South Australia 5005, Australia
}

Chronic pain, encompassing conditions, such as low back pain, arthritis, persistent post-surgical pain, fibromyalgia, and neuropathic pain disorders, is highly prevalent but remains poorly treated. The vast majority of therapeutics are directed solely at neurons, despite the fact that signaling between immune cells, glia, and neurons is now recognized as indispensable for the initiation and maintenance of chronic pain. This review highlights recent advances in understanding fundamental neuroimmune signaling mechanisms and novel therapeutic targets in rodent models of chronic pain. We further discuss new technological developments to study, diagnose, and quantify neuroimmune contributions to chronic pain in patient populations.

Key words: sex differences; TSPO; Nrf2; biomarkers; Fc gamma receptors; cannabinoids

\section{Introduction}

Acute pain serves an adaptive purpose to warn the organism of actual or impending tissue injury. Noxious mechanical, thermal, and chemical stimuli activate primary sensory neurons that transmit nociceptive information to the spinal and medullary dorsal horns. Here, peripheral sensory input is integrated in a complex network of secondary nociceptive neurons that project to supraspinal sites, interneurons, and inhibitory descending projections from brainstem sites (Peirs and Seal, 2016). Secondary projection neurons synapse with tertiary neurons in thalamic and parabrachial nuclei that project to cortical and subcortical regions that encode and perceive pain (Peirs and Seal, 2016). Persistent activation or malfunction of this nociceptive system gives rise to chronic pain. While chronic pain is generally considered to be maladaptive, this concept has recently been challenged (Crook et al., 2014; Lister et al., 2020).

\footnotetext{
Received June 30, 2020; revised Sep. 29, 2020; accepted 0ct. 4, 2020.

P.M.G. receives funding from Biogen Inc. C.I.S. has received consulting fees from Cellectricon and payment for educational lectures from Bristol Myers Squibb, Pfizer, and Eli Lilly. M.L.L. has received consulting fees from Shionogi. M.R.H. receives funding from Regeneus, Abbott, and Novartis. The remaining authors declare no competing financial interests.

This work was supported by National Institutes of Health Grant RF1 NS113840 to P.M.G., K08 NS094547 to V.L.T., K22 NS096030 to M.D.B., and R01 NS095937, R01 NS094306, and R01 DA047088 to M.L.L.; U.S. Army Medical Research and Development Command Grant W81XWH-16-1-0717 and W81XWH-19-1-0160 to P.M.G., and W81XWH-14-1-0543 to M.L.L.; Rita Allen Foundation to P.M.G., V.L.T., and M.D.B.; Brain and Behavior Research Foundation to P.M.G.; Swedish Research Council Grant 542-2013-8373 to C.I.S.; Knut and Alice Wallenberg Foundation to C.I.S.; and Australian Research Council Grant FT180100565 and CE140100003 to M.R.H

Correspondence should be addressed to Peter M. Grace at pgrace@mdanderson.org.

https://doi.org/10.1523/JNEUROSCl.1650-20.2020

Copyright $\odot 2021$ the authors
}

Chronic pain is a pervasive problem affecting 20\% of adults in developed nations (Breivik et al., 2013; Fayaz et al., 2016; Dahlhamer, 2018; Australian Institute of Health and Welfare, 2020). While not fatal, such disorders remain poorly treated and account for the greatest societal burden of disability and disease (Institute for Health Metrics and Evaluation, 2017; James et al., 2018). Some chronic pain conditions, such as arthritis, are characterized by ongoing peripheral nociceptive input related to peripheral inflammation, whereas others, such as neuropathic pain, are a consequence of abnormal functioning of the nervous system because of injury or disease. Yet other chronic pain conditions, such as persistent postsurgical pain, fibromyalgia, and low back pain, may result from a combination of processes. All forms of chronic pain are believed to be maintained, to varying extents, by peripheral sensitization (increased responsiveness and reduced spiking threshold of peripheral nociceptive neurons to stimulation of their receptive fields) (International Association for the Study of Pain, 2017) and central sensitization (increased responsiveness of nociceptive neurons in the CNS to their normal or subthreshold afferent input) (International Association for the Study of Pain, 2017). Research over the past three decades has revealed that such sensitization is not solely the result of direct neuronal communication, but requires cross-talk between neurons, glia, and immune cells (for comprehensive review, see Beggs et al., 2012; Grace et al., 2014, 2016; McMahon et al., 2015; Ji et al., 2016; Kato et al., 2016; Inoue and Tsuda, 2018; Haight et al., 2019; Malcangio, 2019). The field of pain neuroimmunology has nearly tripled its share of all pain research over the past 20 years (Fig. 1). This growth has been led in part by work published in the Journal of Neuroscience (Table 


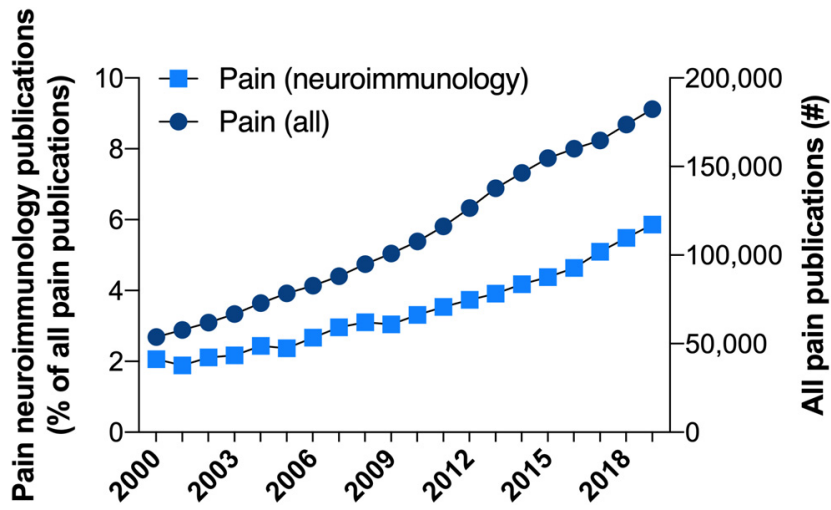

Figure 1. Annual publications on pain and pain neuroimmunology (2000-2019). Total numbers of publications related to pain (pain OR hyperalgesia $O R$ allodynic $O R$ allodynia $O R$ hypernociception $O R$ hypernociceptive $O R$ nociception $O R$ neuropathic) and pain neuroimmunology ((pain OR hyperalgesia OR allodynic OR allodynia OR hypernociception OR hypernociceptive $O R$ nociception $O R$ neuropathic) AND (astrocyte $O R$ astrocytic $O R$ astroglia $O R$ microglia $O R$ oligodendrocyte $O R$ neuroimmune $O R$ neuroimmunology $O R$ neuroinflammation)), between 2000 and 2019, were tabulated from Dimensions using a PubMed limited filter. The pain neuroimmunology publications are expressed as a percentage of the total number of publications related to pain.

Table 1. Top 25 research journals publishing articles related to pain neuroimmunology (2000-2019) ${ }^{a}$

\begin{tabular}{|c|c|c|}
\hline Name & Publications & Average citation rate \\
\hline Journal of Neuroscience & 952 & 81.05 \\
\hline Scientific Reports & 884 & 13.19 \\
\hline Pain & 723 & 52.71 \\
\hline Experimental Neurology & 704 & 39.29 \\
\hline Brain, Behavior, and Immunity & 659 & 42.19 \\
\hline Journal of Neuroinflammation & 651 & 30.37 \\
\hline British Journal of Pharmacology & 488 & 65.59 \\
\hline Molecular Neurobiology & 463 & 24.00 \\
\hline Neurology & 409 & 52.59 \\
\hline Glia & 404 & 51.09 \\
\hline Frontiers in Pharmacology & 394 & 17.13 \\
\hline Journal of Neuroscience Research & 383 & 29.34 \\
\hline Neurobiology of Disease & 320 & 44.33 \\
\hline Anesthesiology & 304 & 39.79 \\
\hline Annals of Neurology & 294 & 78.81 \\
\hline $\begin{array}{l}\text { Proceedings of the National Academy of } \\
\text { Sciences of the United States of America }\end{array}$ & 286 & 81.93 \\
\hline Progress in Neurobiology & 269 & 124.14 \\
\hline Journal of Pain & 252 & 39.74 \\
\hline Frontiers in Immunology & 249 & 26.68 \\
\hline Anesthesia and Analgesia & 248 & 24.37 \\
\hline Pharmacological Research & 219 & 32.11 \\
\hline Journal of Physiology & 210 & 48.62 \\
\hline Neuron & 203 & 142.13 \\
\hline FASEB Journal & 201 & 62.19 \\
\hline Brain & 195 & 95.65 \\
\hline
\end{tabular}

${ }^{a}$ Research journals ranked in the top quartile(s) of their categories are included (web of science). Search terms are provided in Figure 1.

1). In this review, we summarize recent and select advances that will be covered in a mini-symposium on the neuroimmunology of chronic pain.

Immune phenotyping after injury: a focus on sex differences Orthopedic injury or surgery presents a unique challenge because the initiating event may result in polytrauma to muscle, bone, and nerves (Beswick et al., 2012; Mehta et al., 2015).
Moreover, it is estimated that each year in the United States 100,000 bone fractures heal poorly. Accordingly, persistent limb pain is common after such injuries. Because high levels of acute pain increase the risk of developing chronic pain (Hah et al., 2019), likely because of phenomena, such as hyperalgesic priming of primary afferent neurons (Parada et al., 2003; Reichling and Levine, 2009), effective treatment to improve recovery from injury is imperative. Unfortunately, the key components of the multicellular response to injury and how these components can be manipulated to improve outcomes remain unclear (Kehlet and Dahl, 2003).

One important contributor to the development of chronic pain after injury is activation of the immune system. Peripheral injury mobilizes both innate and adaptive branches of the immune system to resolve tissue damage, but persistent immune activation can be detrimental and contribute to delayed healing (Grace et al., 2014; Loi et al., 2016). Notably, immune-system contributions to chronic pain may differ in males and females. Indeed, males are more susceptible to infection from diverse pathogens, reflecting in part a hypoactivation of the innate immune system in males (vom Steeg and Klein, 2016). In contrast, women have a higher prevalence of autoimmune diseases resulting from inappropriate activation of the adaptive immune system (Jacobson et al., 1997). It is therefore crucial to understand sex differences in postinjury immune responses that may result in increased vulnerability to chronic pain, and may carry important treatment implications.

There are some indications from the literature that there are sex-specific immune mechanisms contributing to chronic pain. For example, several studies have highlighted that microglia, the innate immune cells of the CNS, may only maintain pain in males (Sorge et al., 2011, 2015; Agalave et al., 2020). However, not all groups have observed this sexual dimorphism (Peng et al., 2016). Moreover, peripheral macrophage inhibition seems to specifically reverse pain behaviors in male, but not female, mice (Rudjito et al., 2020), suggesting that the immune contribution to pain is likely cell- and location-specific (Lopes et al., 2017).

To evaluate sex differences more comprehensively in the whole-system immune response to injury and its relation to pain progression, Tawfik et al. (2020b) recently characterized a mouse model of orthopedic trauma. The model consists of unilateral tibial fracture with internal fixation and associated injury to the tibialis anterior muscle. These mice exhibit mechanical hypersensitivity in the hindpaw that lasts for $>5$ weeks after injury, making it an appropriate model for studying pain mechanisms. High-dimensional immune profiling was performed at various time points using cytometry by time-of-flight mass spectrometry (Tawfik et al., 2020a). Intracellular signaling pathways in 21 immune cells spanning all major innate and adaptive cell types, as well as individual cell type frequency were assessed, for a total identification of 273 unique immune features. In order to probe this complex, high-parameter dataset, we performed multivariate modeling of the innate and adaptive immune cell responses using a regression method that minimized false positives (Tawfik et al., 2020a). Results suggested that males and females exhibit unique immune profiles: females had a greater neutrophil and dampened $\mathrm{T}$ regulatory cell response in the acute postinjury period, as well as heightened CD4 T memory cell mitogen-activated protein kinase responses in the subacute postinjury period (Tawfik et al., 2020a). T regulatory cells function as a brake on the immune system, specifically limiting autoimmune reactions (Sharma and Rudra, 2018), whereas CD4 T memory cells become activated after antigen presentation and ensure a more 


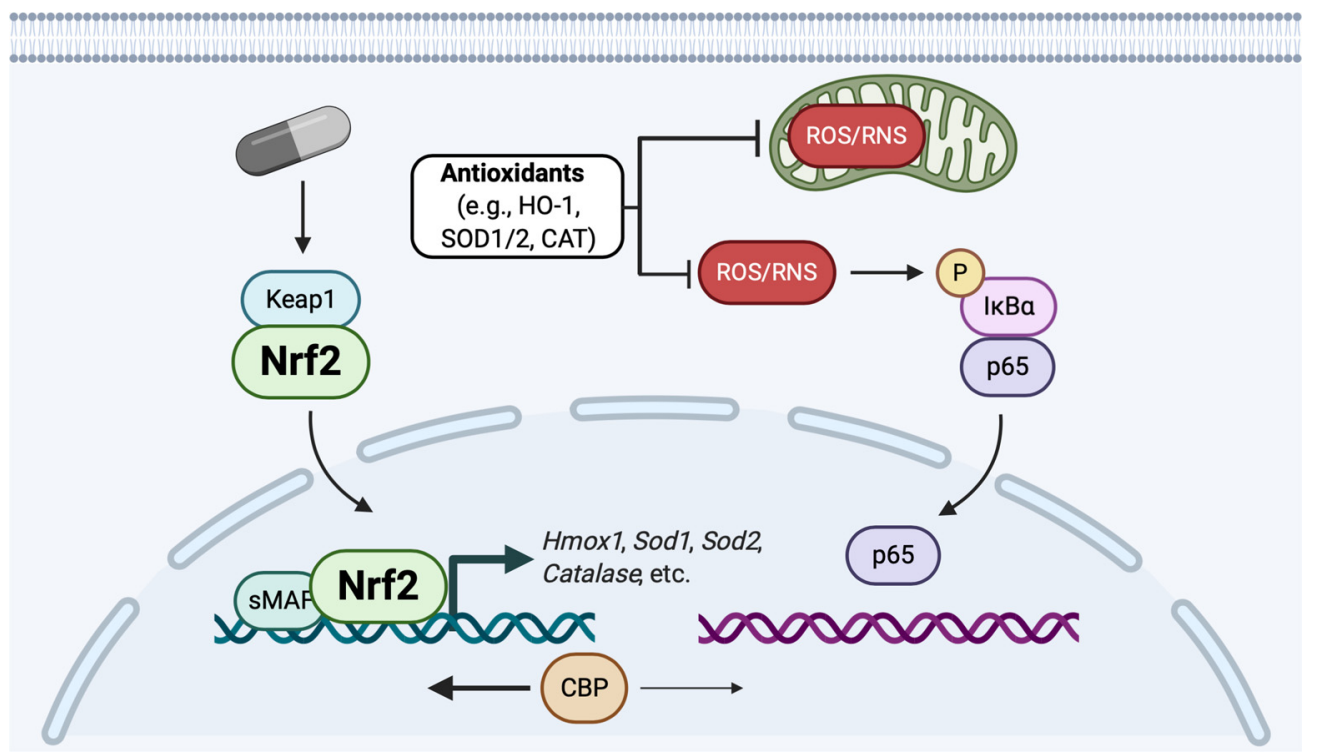

Figure 2. Nrf2 activation alleviates nitro-oxidative stress and neuroinflammation. Pharmacological agents, such as dimethyl fumarate and sulforaphane, can induce nuclear translocation of Nrf2 by disrupting its cytosolic complex with Kelch-like ECH-associated protein 1 (Keap1). Nrf2 binds to DNA, aided by small musculoaponeurotic fibrosarcoma (sMAF) proteins, increasing expression of a suite of antioxidant genes, for example, those encoding heme oxygenase-1 (HO-1), superoxide dismutase (SOD) 1 and 2, catalase (CAT), and others. Antioxidants scavenge ROS/ RNS that otherwise facilitate $\mathrm{I} \kappa \mathrm{B} \alpha$ phosphorylation, inducing $\mathrm{NF} \kappa \mathrm{B}$-dependent proinflammatory gene expression. $\mathrm{NF} \kappa \mathrm{B}$ p65 subunit-DNA binding is further prevented through competition with Nrf2 for CREB-binding protein (CBP). Antioxidants also scavenge ROS/RNS generated by dysfunctional mitochondria. Although not depicted, antioxidants further reduce neuroinflammation by scavenging ROS/RNS that otherwise activate mitogen activated protein kinases.

efficient secondary immune response (Gasper et al., 2014). In combination, these findings indicate an enhanced adaptive immune response to injury in females, with a specific role for $\mathrm{T}$ cell subsets.

A recent comprehensive review highlights several studies in both mice and humans that support a contribution of $\mathrm{T}$ cells to pain (Laumet et al., 2019). The causative role of T-cell subsets in sex-specific responses to injury, and ultimately vulnerability to chronic pain, has been investigated in one prior preclinical study (Sorge et al., 2015). In this study, the PPAR $\gamma$ agonist pioglitazone reversed nerve injury-induced pain behaviors only in females, presumably through suppression of interferon- $\gamma$, a cytokine produced in greater amounts by female $\mathrm{T}$ cells (Zhang et al., 2012). In contrast, other groups have found that pioglitazone attenuates neuropathic pain behaviors in males (Griggs et al., 2015; Lyons et al., 2017; Khasabova et al., 2019). Therefore, this remains an area of active research.

The details of the immune response to injury and how it contributes to the transition from acute to chronic pain are a complex and exciting area for future inquiry. As such research moves from preclinical to clinical studies, future results will open new avenues for the exploration of sex-specific treatment paradigms for patients with chronic pain.

Regulatory role of nuclear factor erythroid 2-related factor 2 (Nrf2) in neuroimmune-nitro-oxidative stress interactions Neuroinflammatory signaling is intertwined with other pathologic processes underlying neuropathic pain, including overproduction of reactive oxygen and nitrogen species (ROS/RNS) (nitro-oxidative stress) and mitochondrial dysfunction (Salvemini et al., 2011; Janes et al., 2012; Little et al., 2012; Bennett et al., 2014; Symons-Liguori et al., 2016). For example, danger-associated molecular patterns can activate pattern recognition receptors, such as Toll-like receptors, to drive transcription of inducible nitric oxide synthase and activation of NAPDH oxidases that produce nitric oxide and ROS (Grace et al., 2016; Kato et al., 2016; Lacagnina et al.,
2018). Reciprocally, ROS/RNS induce expression of proinflammatory mediators by activating mitogen-activated protein kinases and nuclear factor $\kappa \mathrm{B}(\mathrm{NF} \kappa \mathrm{B})$, both directly and via receptors like TRPM2 expressed by glia and leukocytes (Grace et al., 2016). Injury-induced ROS/RNS can damage mitochondria in nociceptive pathways, causing the organelles to leak ROS and danger-associated molecular patterns that activate inflammasomes and Toll-like receptors (Grace et al., 2016, 2018; Kato et al., 2016; Próchnicki et al., 2016; Lacagnina et al., 2018). Collectively, inflammatory mediators and ROS/RNS promote sensitization through direct activation of neuronal ion channels, as well as neuromodulation and dysfunctional synaptic plasticity via well-characterized mechanisms, described previously in detail (Salvemini et al., 2011; Beggs et al., 2012; Grace et al., 2014, 2016; McMahon et al., 2015; Ji et al., 2016; Inoue and Tsuda, 2018; Haight et al., 2019; Malcangio, 2019). Simultaneously resolving neuroinflammation and nitro-oxidative stress could be an improved strategy for relief of neuropathic pain.

Nrf2, also known as NFE2L2, is a potential therapeutic target to alleviate neuroinflammation and nitro-oxidative stress (Fig. 2). The transcription factor increases expression of a suite of antioxidant and cyto-protective genes in response to oxidants (Dodson et al., 2018; Cuadrado et al., 2019). Subsequent detoxification of ROS/RNS reduces downstream inflammatory signaling. In addition, Nrf2 exerts direct anti-inflammatory actions by attenuating $\mathrm{NF} \kappa \mathrm{B}$ activity (Wardyn et al., 2015). While this endogenous regulator normally buffers nitro-oxidative stress, for unknown reasons, the Nrf2 pathway fails to adequately detoxify pathologic levels of ROS/RNS after injury.

Notably, there is evidence that pharmacological activation of Nrf2 can alleviate neuropathic pain in preclinical models. For example, using a model of peripheral nerve injury, Grace and colleagues recently showed that dimethyl fumarate reverses allodynia and hyperalgesia in reflex and operant assays ( $\mathrm{Li}$ et al., 2020). At the same time, dimethyl fumarate induced nuclear translocation (activation) of Nrf2 in the DRGs, which contains 
the cell bodies of sensory neurons, and increased expression of antioxidant target genes and enzyme activity (superoxide dismutase, glutathione) (Li et al., 2020). Confirming Nrf2 as a major therapeutic target in both sexes, the antinociceptive effects of dimethyl fumarate were lost in male and female $N r f 2^{-1-}$ mice or when dimethyl fumarate was coadministered with the Nrf2 inhibitor trigonelline (Li et al., 2020). These results complement previous work showing another well-known Nrf2 activator, sulforaphane, both prevented and dose-dependently reversed mechanical allodynia and thermal hyperalgesia induced by peripheral nerve injury or the chemotherapy, oxaliplatin (Kim et al., 2010; C. Wang and Wang, 2017; Ferreira-Chamorro et al., 2018; Yang et al., 2018), and that the antinociceptive efficacy of sulforaphane was lost in Nrf2 $2^{-1-}$ mice (Yang et al., 2018).

Nrf2 activators may alleviate neuropathic pain by normalizing mitochondrial and microglial function. Dimethyl fumarate and sulforaphane reversed mitochondrial dysfunction in sensory neurons caused by peripheral nerve injury and by the chemotherapeutic agent, oxaliplatin, respectively (Yang et al., 2018; Li et al., 2020). While the mechanisms linking mitochondrial damage to increased neuronal excitability or spontaneous activity are not yet fully understood, normalizing mitochondrial function attenuates evoked and ongoing pain (Bennett et al., 2014). Dimethyl fumarate and sulforaphane also attenuated injuryinduced microglial activation and increases in proinflammatory cytokines and ROS in the pain neuraxis (Kim et al., 2010; C. Wang and Wang, 2017; Ferreira-Chamorro et al., 2018; Li et al., 2020). These pharmacological data from several groups indicate that Nrf2 activation alleviates neuropathic pain and underlying mechanisms in preclinical models.

The protective role of Nrf2 in neuropathic pain is an emerging area of investigation, with several questions to be addressed in future studies. Evidence is mixed regarding whether Nrf2 is appreciably activated after peripheral nerve injury (Yang et al., 2018; Li et al., 2020). However, Nrf2 still serves a protective role, as mechanical allodynia induced by oxaliplatin treatment was exacerbated in $\mathrm{Nrf2^{-1- }}$ mice compared with WT mice (Yang et al., 2018). Spatiotemporal analysis of the endogenous role of Nrf2 after injury is still required. The cells for whom Nrf2 activation is protective, and the neuroanatomical locations in which they reside, are still to be identified. Such investigation could support Nrf2 as a therapeutic target, as it sits at the nexus of several major mechanisms that underlie neuropathic pain.

\section{Contributions of autoantibodies and neuronal $\mathrm{Fc} \gamma$ receptors to joint pain in arthritis}

Pain is one of the most problematic symptoms for patients with rheumatoid arthritis (RA). Pain in RA has traditionally been attributed to the inflammatory process in the joint, but it is becoming increasingly clear that other mechanisms are also at play. During the period immediately before diagnosis, individuals frequently suffer from joint pain, often without signs of joint inflammation (de Hair et al., 2014). Furthermore, pain still persists in a sizable proportion of RA patients for whom other RA symptoms, including joint inflammation, are medically controlled (Taylor et al., 2010). Thus, joint pain uncoupled from apparent disease activity is a pervasive problem and represents a fundamental gap in our mechanistic understanding of pain in autoimmune disorders.

A joint pathology similar to human RA can be induced in rodents by immunizing animals with collagen Type II, a structural protein mainly found in articular cartilage, or by transferring monoclonal anti-collagen II antibodies (Holmdahl et al.,
1986; Terato et al., 1992; Lindh et al., 2014). Using the collagenantibody-induced arthritis model (Nandakumar et al., 2003), Svensson and colleagues observed that pain-related behaviors develop before any signs of joint inflammation and remains for weeks after the inflammation has subsided (Bas et al., 2012; Agalave et al., 2014; Su et al., 2015). Other antibodies binding to cartilage, such as cartilage oligomeric matrix protein, were also found to elicit mechanical hypersensitivity uncoupled from visual, histologic, and molecular indications of inflammation in mice (Bersellini Farinotti et al., 2019). Because cartilage is not innervated, the anti-cartilage antibodies must act on other targets to mediate pronociceptive effects in the pre-inflammatory stage. Mice lacking functional complement 5 or treated with a complement 5 receptor antagonist still developed pain behaviors induced by anti-collagen II antibody. This suggests that cartilage-antibodyinduced pain-related behaviors do not depend on joint inflammation or complement 5 (and thereby terminal/lytic complement), but instead on tissue antigen recognition, local immune-complex formation, and activation of neuronally expressed Fc $\gamma$ receptors.

Fc $\gamma$ receptors are bound by immunoglobulin G (IgG) antibody and may activate (e.g., Fc $\gamma$ receptors I, III, and IV) or inhibit (e.g., Fc $\gamma$ receptor IIb) cells based on the cytoplasmic tyrosine-based motif associated with the receptor. Recent work from several groups has demonstrated that nociceptors express Fc $\gamma$ receptor I that are activated by IgG after they have bound antigen and formed an antibody-antigen complex (immune complex) (Qu et al., 2011, 2012; L. Wang et al., 2019). Svensson and colleagues discovered that not only the activating Fc $\gamma$ receptor I, but also the inhibitory $\mathrm{Fc} \gamma$ receptor IIb, are present in the peripheral terminals of primary afferents in uninjured mice. Focusing on the phase before inflammation, preformed collagen II antibody-antigen immune complexes directly activated cultured DRG WT neurons, but not neurons lacking activating Fc $\gamma$ Rs. In line with this observation, anti-collagen II antibodies and collagen II immune complexes did not induce mechanical hypersensitivity in Fc receptor $\gamma$-chain ${ }^{-1-}$ mice (which lack cell surface expression and signaling of all activating Fc $\gamma$ receptors), or mice lacking activating $\mathrm{F}_{\mathrm{c}} \gamma$ receptors in neurons. Furthermore, anti-collagen II antibodies that retain their ability to bind collagen II but either lack the $\mathrm{Fc}$ region or have a reduced affinity for $\mathrm{Fc} \gamma$ receptors were not pronociceptive, indicating that the Fc-Fc $\gamma$ receptor interaction is critical for development of collagen II antibody-induced pain-related behaviors. Fc $\gamma$ receptor III and IV deficiency did not prevent collagen II antibody responses, which supports an important role of Fc $\gamma$ receptor I in the direct action of immune complexes on nociceptors. It is unlikely that $\mathrm{Fc} \gamma$ receptor IIb is coupled to enhancement of neuronal excitability because Fc receptor $\gamma$-chain deficient mice were protected against the pronociceptive actions of cartilage-associated antibodies despite expression of Fc $\gamma$ receptor IIb (Bersellini Farinotti et al., 2019). Nevertheless, the presence of $\mathrm{Fc} \gamma$ receptor IIb in sensory neurons is interesting and warrants further investigation, as the receptor could be linked to inhibitory mechanisms in neurons during established disease.

In summary, studies from Svensson and colleagues show that cartilage antibody immune complexes, which are highly correlated with early RA and joint pathology, serve as key triggers for pain behavior in the early phase of the disease via activation Fc $\gamma$ receptor I on nociceptors, without generating histologic or biochemical signs of inflammation. These studies point to a functional coupling between autoantibodies and pain transmission, which may be at play before and subsequent to flares of active disease. Together, the identification of novel contributions of 
autoantibodies to persistent pain may aid in the development of new treatment strategies, not only for pain in RA, but also for pain in other diseases associated with autoantibody production, such as Sjögren's syndrome, systemic lupus erythematosus, and Guillain-Barré syndrome.

\section{Cannabinoid receptor Type 1 (CB1R) as a neuroimmune therapeutic target for chronic pain}

Preclinical studies in the neuroimmunology of chronic pain have revealed numerous potential therapeutic targets. Among these, $\mathrm{CB1R}$ has been identified as a viable candidate in controlling pain and inflammation (Kunos et al., 2009; Milligan et al., 2020). Global CB1R KO studies have demonstrated the necessity of CB1R action for both endogenous and therapeutically induced pain inhibition (Sideris et al., 2016; Bajic et al., 2018). Although these studies have established the analgesic function of CB1R, they have failed to distinguish the most critical loci for analgesic action. CB1R is one of the most abundantly expressed GPCRs in the entire nervous system, and studies are mixed regarding the loci of CB1R analgesic action (Martin et al., 1995; Fox et al., 2001; Meng and Johansen, 2004; Agarwal et al., 2007; PerníaAndrade et al., 2009; Skaper and Di Marzo, 2012; Lu and Mackie, 2016). Indeed, the function of cannabinoids is governed by their site of action, and overlapping expression patterns in the nervous system make it difficult to tease out the analgesic, metabolic, and psychoactive sites of actions of cannabinoids.

How CB1R specifically modulates pain processing is an ongoing area of study and there is intense debate regarding whether peripheral or CNS activation of CB1R is more critical to produce analgesic effects (Milligan et al., 2020). In the periphery, CB1R is expressed on DRG neurons and various other cell types (Mackie, 2005; Ständer et al., 2005), while in the CNS, GABAergic interneurons in the dorsal horn of the spinal cord, brainstem, and amygdala are putative sites of CB1R action (Navarrete et al., 2020). While sensory neurons have the capacity to powerfully regulate immune responses (Pinho-Ribeiro et al., 2017), it is unclear whether CB1R expression by sensory neurons or macrophages regulates inflammation after injury (Amaya et al., 2006). This is an important distinction, as the anti-inflammatory effects of CB1R through expression on immune cells is a recent finding (Cinar et al., 2017; Jourdan et al., 2017; Joffre et al., 2020).

The identity of the peripheral cell that is responsible for immune modulation is a major source of contention in translational studies (Kunos et al., 2009; Pacher and Kunos, 2013). Despite the fact that cannabinoids have a long history in medicinal use, major drawbacks, including psychotropic effects, have led to extended lines of enquiry aimed at parsing central effects from peripheral analgesic actions (Pacher et al., 2006). Interestingly, the debate has led to the development of peripherally restricted cannabinoids, designed to circumvent various unwanted central effects (Seltzman et al., 2016). However, peripherally restricted synthetic CB1R agonists have not produced analgesia in clinical trials (Kalliomäki et al., 2013a,b). To date, the outcome of clinical and preclinical studies is mixed with an overwhelming majority of clinical trials of cannabinoid agonists failing because of analgesic efficacy, kidney damage, and absence of longitudinal data (Kunos et al., 2009; Kunos and Tam, 2011; Pacher and Kunos, 2013; Finnerup et al., 2015). Identifying the CB1R cell types that mediate the analgesic actions of cannabinoids is imperative to realizing the anti-inflammatory and analgesic potential of CB1R agonists (DeMarco and Nunamaker, 2019).

\section{Neuroinflammation in human chronic pain states}

Despite a large preclinical literature demonstrating a key role of neuroinflammation in the CNS in animal pain models (glial activation and attendant production of proinflammatory mediators) (Beggs et al., 2012; Grace et al., 2014; McMahon et al., 2015; Ji et al., 2016; Inoue and Tsuda, 2018; Malcangio, 2019), the role of neuroinflammation in human pain is still unknown. Sampling of CSF and analysis of postmortem spinal cord samples suggest that glial activation may occur in patients with various types of chronic pain (Brisby et al., 1999; Del Valle et al., 2009; Kadetoff et al., 2012; Shi et al., 2012; Kosek et al., 2015; Bäckryd et al., 2017), but the ability to "visualize" neuroinflammation in living patients long remained elusive. In the last few years, the use of PET with radioligands targeting the $18 \mathrm{kDa}$ translocator protein (TSPO) has begun to fill this gap. TSPO is a five-transmembrane domain protein expressed on mitochondria (Papadopoulos et al., 2006) and thus is found in cells in addition to glia (Batarseh and Papadopoulos, 2010; Wei et al., 2013). Nevertheless, TSPO can serve as a marker of neuroinflammation because this protein, for reasons that are not fully understood, is dramatically upregulated in activated microglia and astrocytes. Indeed, a strong colocalization between TSPO upregulation and activated glial cells has been found across multiple preclinical and human studies of various disorders, including neurodegeneration. Hence, TSPO is intensively used to image neuroinflammation (Banati et al., 2000; Ji et al., 2008; Cosenza-Nashat et al., 2009; Alshikho et al., 2018; Lois et al., 2018; Barletta et al., 2020).

In preclinical studies of arthritis, complex regional pain syndrome, and lumbar radiculopathy, TSPO was upregulated concomitantly with glial activation (Hernstadt et al., 2009; Wei et al., 2013; Cropper et al., 2019; Guilarte, 2019), supporting the use of TSPO as a marker of glial activation. Using a second-generation TSPO radioligand ( $\left.\left[{ }^{11} \mathrm{C}\right] \mathrm{PBR} 28\right)$, Loggia et al. have demonstrated increased TSPO signal in the brains of patients with chronic low back pain, fibromyalgia, migraine and veterans suffering from Gulf War Illness, as well as in the spinal cord of patients with lumbar radiculopathy (Fig. 3) (Loggia et al., 2015; Albrecht et al., 2018, 2019a,c; Alshelh et al., 2020). The signal appears to exhibit specific spatial distribution across disorders. For instance, thalamic signal elevation is the most consistent finding for chronic low back pain (an observation that was recently replicated in an independent cohort) (Torrado-Carvajal et al., 2020), whereas cortical regions are mainly involved in other conditions, such as fibromyalgia (Loggia et al., 2015; Albrecht et al., 2019a). Furthermore, along with the primary somatosensory cortex (S1), the TSPO signal was elevated in the lumbar spine cortical representation in chronic low back pain, in a ventrolateral aspect of S1 compatible with the face area in migraine, and in a large portion of the sensorimotor strip in patients suffering from widespread body pain (fibromyalgia) (Loggia et al., 2015; Albrecht et al., 2019a,c). Together, these observations suggest that neuroinflammation, as assessed by TSPO signal elevation (1) might be a pervasive phenomenon observed across multiple, etiologically heterogeneous human pain disorders and (2) might present itself in disorder-specific spatial distributions, paralleling the specific body distribution of the pain experienced by each patient group.

Certainly, the biological and clinical significance of the observed TSPO signal elevations in chronic pain disorders remains to be elucidated. First, while this signal might correlate "spatially" with the body distribution of pain disorders, to date, the relationship between TSPO signal elevations and disorder severity has been inconsistent. For instance, brain TSPO signal was found to be positively correlated with frequency of migraine attacks in migraineurs, with fatigue severity in patients with 
A

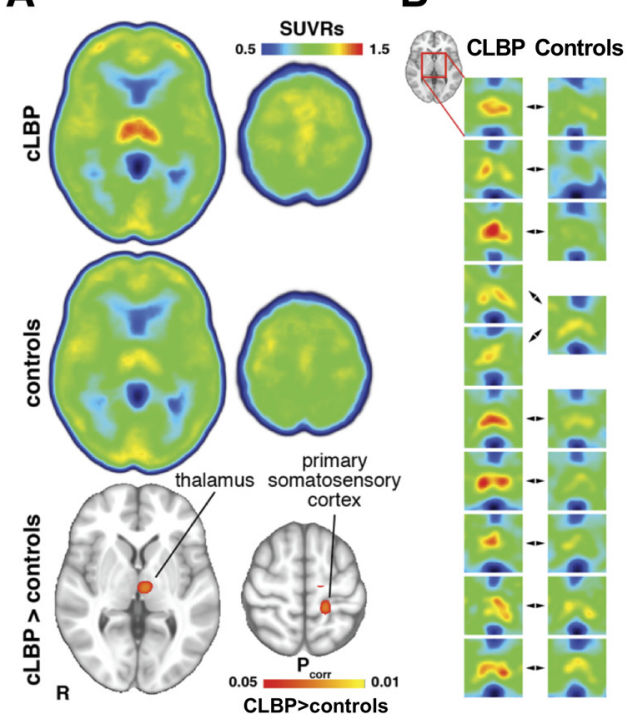

C

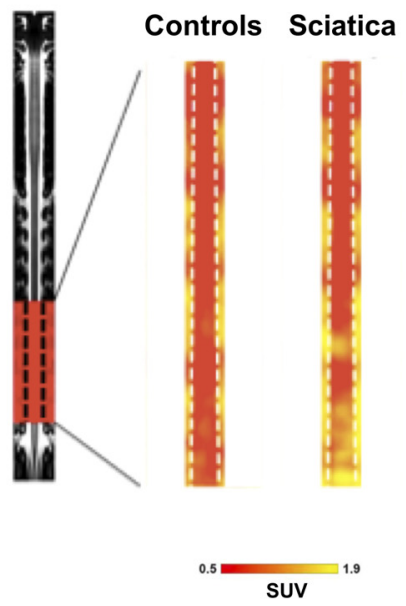

D

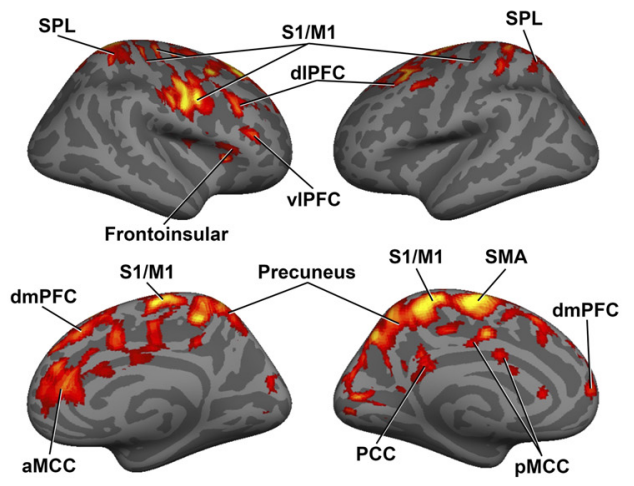

Fibromyalgia > controls

Figure 3. TSPO ([ $\left.\left.{ }^{11} \mathrm{C}\right] \mathrm{PBR} 28\right)$ signal increases in chronic pain patients. $\boldsymbol{A}$, Brain TSPO signal elevation in chronic low back pain (cLBP) patients (median images and group comparison). $\boldsymbol{B}$, Individual data showing consistently higher thalamic $\left[{ }^{11} \mathrm{C}\right]$ PBR28 signal in patients, compared with sex-, age-, and binding affinity-matched controls (Loggia et al., 2015$)$. C, $\left[{ }^{11} \mathrm{C}\right] \mathrm{PBR} 28$ signal elevations in the lower spinal cord segments in patients with radicular LBP ("Pain target") compared with reference region ("Pain reference") and healthy controls ("Control") (Albrecht et al., 2018). D, [ $\left.{ }^{11} \mathrm{C}\right]$ PBR28 signal elevation in patients with fibromyalgia (Albrecht et al., 2019a).

fibromyalgia, and with depressive scores in chronic low back pain patients with comorbid negative affect (Albrecht et al., 2019a,b,c). At the same time, this signal was reported to be either not associated with, or even inversely related to, pain severity in chronic low back pain and arthritis (Loggia et al., 2015; Forsberg et al., 2019). Moreover, while TSPO upregulation in neuroinflammatory responses consistently colocalizes with microglia, an accompanying astrocytic component has been observed in some cases (Rupprecht et al., 2010; Wei et al., 2013; Liu et al., 2016). Furthermore, TSPO does not appear to differentiate immune phenotypes (i.e., proinflammatory vs anti-inflammatory), although some evidence suggests that TSPO upregulation may favor the resolution of neuroinflammation, possibly through the stimulation of steroidogenesis (Batarseh and Papadopoulos, 2010; Wei et al., 2013; Bae et al., 2014; M. Wang et al., 2014).

While many questions remain to be answered, a growing literature nonetheless suggests that neuroinflammation occurs in clinical chronic pain states, adding further weight to the preclinical support of glial modulation as a therapeutic strategy. Importantly, because pain-related TSPO upregulation has been described in both human and preclinical pain studies, the study of this protein potentially offers major reverse-translational opportunities, whereby human imaging results can inform mechanistic evaluations of the role of TSPO in animals. These approaches, together with the development of novel radioligands targeting more specific immune cell subtypes and phenotypes (Narayanaswami et al., 2018), are likely to lead to significant advances in our understanding of the role of neuroinflammation in human chronic pain.

\section{Development of neuroimmune biomarkers of pain}

Chronic pain has a complex, multisystem etiology, involving interactions between genes and environment. The advent of precision medicine that allows personalization of treatments in fields, such as cancer based on mechanistic biomarkers of complex phenotypes, have not yet been applied to the treatment of
Table 2. Ratio of publications to patents and clinical trials for pain neuroimmunology and pain (2000-2019) ${ }^{a}$

\begin{tabular}{|c|c|c|c|c|}
\hline & \multicolumn{2}{|c|}{ Pain (neuroimmunology) } & \multicolumn{2}{|l|}{ Pain (all) } \\
\hline & $\begin{array}{l}\text { Total } \\
\text { numbers }\end{array}$ & $\begin{array}{l}\text { Ratio of } \\
\text { publications to } X\end{array}$ & $\begin{array}{l}\text { Total } \\
\text { numbers }\end{array}$ & $\begin{array}{l}\text { Ratio of } \\
\text { publications to } X\end{array}$ \\
\hline Publications & 201,683 & 1.00 & $4,422,911$ & 1.00 \\
\hline Patents & 43,198 & 4.66 & 435,852 & 10.15 \\
\hline Clinical trials & 111 & 1816.96 & 12,284 & 360.05 \\
\hline
\end{tabular}

${ }^{a}$ Search terms are provided in Figure 1. Data were tabulated from dimensions using a PubMed limited filter.

chronic pain. Major technological advances have already occurred to aid in the management of other disorders of the nervous system. For example, imaging platforms, such as fMRI, PET, and measurements from EEG, have changed the way diseases, such as epilepsy, are diagnosed and treated (Patel et al., 2019). However, these advances are somewhat isolated, and the identification and quantification of pain are still reliant on subjective diagnosis and empirical treatment selection. This clinical predicament creates a significant burden on the individual and profound health economic waste, with patients waiting up to 1 year after experiencing symptoms before presenting to a physician, and then taking $>2$ years and presenting to up to four different physicians before receiving a diagnosis for some complex chronic pain conditions (Choy et al., 2010).

The research activities of the Australian Research Council Centre of Excellence for Nanoscale BioPhotonics have sought to identify novel biomarkers of pain and to create measurement technologies that will allow pain diagnosis and direct precision medicine treatment of chronic pain. The criteria for such technologies are sensitivity and precision but must also deliver actionable information within a clinically meaningful timeframe and cost-effective strategy. Such measurements of chronic pain need to account for the sensory and emotional dimensions of chronic pain in addition to the aforementioned gene-environment-multisystem biology etiology of diseases of the CNS. The team rationalized that the pain state of an individual could be 
quantified from peripheral blood because a priori, peripheral blood represents the accumulated environmental and genetic state of the individual. These collective changes in cellular state and proteome content of the blood are impacted by the emotional and physiological state of the individual causally linked to the sensory and emotional dimensions of chronic pain, given that peripheral immune cells support pain mechanisms in the CNS (Grace et al., 2011a,b; Wohleb et al., 2013; Sawicki et al., 2018). The hypothesis is supported by work showing that the $e x$ vivo activity of peripheral immune cells can be used to stratify patients into chronic pain and healthy populations (Kwok et al., 2012; Evans et al., 2020).

Hyperspectral imaging of biology is emerging as an analytical tool that can be harnessed to improve research efficiency, lead to novel discoveries, and guide point-of-care decisions. Simultaneous integration of the emission spectra from multiple excitation wavelengths can provide substantial quantitative information about native fluorophores in individual cells in a mixed cell population. This analytical approach can then be used to rapidly phenotype entire cell populations in a label-free approach. For example, markers of mitochondrial oxidative stress/mitochondrial function/dysfunction (free $\mathrm{NADH}$, bound $\mathrm{NADH}$, flavoproteins, including flavin adenine dinucleotide-containing flavoproteins pyruvate dehydrogensase, ketoglutumate dehydrogenase, and electron transfer flavoproteins, retinoids, e.g., A2E, lipofuscin, and cytochrome c) can be quantified using hyperspectral analysis and linked to pain behaviors (Staikopoulos et al., 2016; Mahbub et al., 2019; Habibalahi et al., 2020) Alternatively, unsupervised analysis can be used to explore the $n$-dimensional data frames for spectral features that are predictive of pain states with nonlinear machine learning used to extract the clinically relevant signal. Preclinical and clinical trials are identifying hyperspectral signatures from a simple blood sample or a complex spinal cord tissue that can delineate healthy patients from those with chronic pain. Importantly, the technology and consumables can be produced at a very cost-effective unit per measurement; and owing to the ability to use microfluidics within sample processing, the test results can be available within minutes. Excitingly, this approach is also allowing the identification of the discrete subpopulations of cells, both centrally and peripherally, that are driving the spectral diagnosis and could be associatively and/or mechanistically linked to the exaggerated pain state.

In conclusion, since the first publications linking neuroinflammation to chronic pain more than two decades ago (Garrison et al., 1991; Svensson et al., 1993; Meller et al., 1994; Watkins et al., 1997; Colburn et al., 1999), the dividing line between the nervous and immune systems has become increasingly blurred. Sensory neurons express classical immune receptors, such as Fc $\gamma$ receptors, that enable them to directly transduce signals from immune cells. Secreted immune mediators, such as ROS/RNS, directly activate ion channels that are classically expressed by sensory neurons. Sensory neurons can reciprocally regulate immune cell activity following stimulation of a variety of receptors, including CB1Rs. Connecting all of these discoveries is an increasing appreciation for how the immune response to injury is differentially regulated between the sexes.

Despite these continuing advances, the field of pain neuroimmunology is not yet translating basic science to the clinic at the same rate as the pain field in general; there is a fivefold difference in the ratio of publications to clinical trials (Table 2). This could be explained by the relative immaturity of the subfield. Excitingly, however, patents related to pain neuroimmunology have been filed at more than double that of the broader pain field over the past 20 years (Table 2). Facilitated by the recent insights afforded by PET imaging into how central neuroinflammation is manifested in patients with chronic pain, together with the promise of peripherally accessible neuroimmune biomarkers of pain, we may be on the cusp of exciting discoveries. This decade may see an explosion in translational activity through active recruitment of clinicians and technologists into the field of chronic pain neuroimmunology.

\section{References}

Agalave NM, Larsson M, Abdelmoaty S, Su J, Baharpoor A, Lundbäck P, Palmblad K, Andersson U, Harris H, Svensson CI (2014) Spinal HMGB1 induces TLR4-mediated long-lasting hypersensitivity and glial activation and regulates pain-like behavior in experimental arthritis. Pain 155:18021813.

Agalave NM, Rudjito R, Farinotti AB, Khoonsari PE, Sandor K, Nomura Y, Szabo-Pardi TA, Urbina CM, Palada V, Price TJ, Harris HE, Burton MD, Kultima K, Svensson CI (2020) Sex-dependent role of microglia in disulfide HMGB1-mediated mechanical hypersensitivity. Pain. Advance online publication. Retrieved Aug 5, 2020. doi: 10.1097/j. pain.0000000000002033.

Agarwal NM, Pacher P, Tegeder I, Amaya F, Constantin CE, Brenner CJ, Rubino T, Michalski CW, Marsicano G, Monory K, Mackie K, Marian C, Batkai S, Parolaro D, Fischer MJ, Reeh P, Kunos G, Kress M, Lutz B, Woolf CJ, et al. (2007) Cannabinoids mediate analgesia largely via peripheral type 1 cannabinoid receptors in nociceptors. Nat Neurosci 10:870-879.

Australian Institute of Health and Welfare (2020) Chronic pain in Australia. Canberra, Australia: Australian Institute of Health and Welfare.

Albrecht DS, Ahmed SU, Kettner NW, Borra RJ, Cohen-Adad J, Deng H, Houle TT, Opalacz A, Roth SA, Melo MF, Chen L, Mao J, Hooker JM, Loggia ML, Zhang Y (2018) Neuroinflammation of the spinal cord and nerve roots in chronic radicular pain patients. Pain 159:968-977.

Albrecht DS, Fosberg A, Sandström A, Bergan C, Kadetoff D, Protsenko E, Lampa J, Lee YC, Höglund CO, Catana C, Cervenka S, Akeju O, Lekander M, Cohen G, Halldin C, Taylor N, Kim M, Hooker JM, Edwards RR, Napadow V, et al. (2019a) Brain glial activation in fibromyalgia: a multi-site positron emission tomography investigation. Brain Behav Immun 75:72-83.

Albrecht DS, Kim M, Akeju O, Torrado-Carvajal A, Edwards RR, Zhang Y, Bergan C, Protsenko E, Kucyi A, Wasan AD, Hooker JM, Napadow V, Loggia ML (2019b) The neuroinflammatory component of negative affect in patients with chronic pain. Mol Psychiatry, in press.

Albrecht DS, Mainero C, Ichijo E, Ward N, Granziera C, Zürcher NR, Akeju O, Bonnier G, Price J, Hooker JM, Napadow V, Loggia ML, Hadjikhani $\mathrm{N}$ (2019c) Imaging of neuroinflammation in migraine with aura: a $\left[{ }^{11} \mathrm{C}\right]$ PBR28 PET/MRI study. Neurology 92:e2038-e2050.

Alshelh Z, Albrecht DS, Bergan C, Akeju O, Clauw DJ, Conboy L, Edwards RR, Kim M, Lee YC, Protsenko E, Napadow V, Sullivan K, Loggia ML (2020) In-vivo imaging of neuroinflammation in veterans with Gulf War illness. Brain Behav Immun 87:498-507.

Alshikho MJ, Zürcher NR, Loggia ML, Cernasov P, Reynolds B, Pijanowski O, Chonde DB, Izquierdo Garcia D, Mainero C, Catana C, Chan J, Babu S, Paganoni S, Hooker JM, Atassi N (2018) Integrated magnetic resonance imaging and [ $\left.{ }^{11} \mathrm{C}\right]-\mathrm{PBR} 28$ positron emission tomographic imaging in amyotrophic lateral sclerosis. Ann Neurol 83:1186-1197.

Amaya F, Shimosato G, Kawasaki Y, Hashimoto S, Tanaka Y, Ji RR, Tanaka M (2006) Induction of CB1 cannabinoid receptor by inflammation in primary afferent neurons facilitates antihyperalgesic effect of peripheral CB1 agonist. Pain 124:175-183.

Bäckryd E, Tanum L, Lind AL, Larsson A, Gordh T (2017) Evidence of both systemic inflammation and neuroinflammation in fibromyalgia patients, as assessed by a multiplex protein panel applied to the cerebrospinal fluid and to plasma. J Pain Res 10:515-525.

Bae KR, Shim HJ, Balu D, Kim SR, Yu SW (2014) Translocator protein 18 $\mathrm{kDa}$ negatively regulates inflammation in microglia. J Neuroimmun Pharmacol 9:424-437. 
Bajic D, Monory K, Conrad A, Maul C, Schmid RM, Wotjak CT, SteinThoeringer CK (2018) Cannabinoid receptor type 1 in the brain regulates the affective component of visceral pain in mice. Neuroscience 384:397405.

Banati RB, Newcombe J, Gunn RN, Cagnin A, Turkheimer F, Heppner F, Price G, Wegner F, Giovannoni G, Miller DH, Perkin GD, Smith T, Hewson AK, Bydder G, Kreutzberg GW, Jones T, Cuzner ML, Myers R (2000) The peripheral benzodiazepine binding site in the brain in multiple sclerosis: quantitative in vivo imaging of microglia as a measure of disease activity. Brain 123:2321-2337.

Barletta VT, Herranz E, Treaba CA, Ouellette R, Mehndiratta A, Loggia ML, Klawiter EC, Ionete C, Jacob SA, Mainero C (2020) Evidence of diffuse cerebellar neuroinflammation in multiple sclerosis by ${ }^{11} \mathrm{C}-\mathrm{PBR} 28 \mathrm{MR}-$ PET. Mult Scler 26:668-678.

Bas DB, Su J, Sandor K, Agalave NM, Lundberg J, Codeluppi S, Baharpoor A, Nandakumar KS, Holmdahl R, Svensson CI (2012) Collagen antibodyinduced arthritis evokes persistent pain with spinal glial involvement and transient prostaglandin dependency. Arthritis Rheum 64:3886-3896.

Batarseh A, Papadopoulos V (2010) Regulation of translocator protein 18 $\mathrm{kDa}$ (TSPO) expression in health and disease states. Mol Cell Endocrinol 327:1-12.

Beggs S, Trang T, Salter MW (2012) P2X4R ${ }^{+}$microglia drive neuropathic pain. Nat Neurosci 15:1068-1073.

Bennett GJ, Doyle T, Salvemini D (2014) Mitotoxicity in distal symmetrical sensory peripheral neuropathies. Nat Rev Neurol 10:326-336.

Bersellini Farinotti A, Wigerblad G, Nascimento D, Bas DB, Urbina CM, Nandakumar KS, Sandor K, Xu B, Abdelmoaty S, Hunt MA, Möller KA, Baharpoor A, Sinclair J, Jardemark K, Lanner JT, Khmaladze I, Borm LE, Zhang L, Wermeling F, Cragg MS, et al. (2019) Cartilage-binding antibodies induce pain through immune complex-mediated activation of neurons. J Exp Med 216:1904-1924.

Beswick AD, Wylde V, Gooberman-Hill R, Blom A, Dieppe P (2012) What proportion of patients report long-term pain after total hip or knee replacement for osteoarthritis? A systematic review of prospective studies in unselected patients. BMJ Open 2:e000435.

Breivik H, Eisenberg E, O'Brien T (2013) The individual and societal burden of chronic pain in Europe: the case for strategic prioritisation and action to improve knowledge and availability of appropriate care. BMC Public Health 13:1229.

Brisby H, Olmarker K, Rosengren L, Cederlund CG, Rydevik B (1999) Markers of nerve tissue injury in the cerebrospinal fluid in patients with lumbar disc herniation and sciatica. Spine 24:742-746.

Choy E, Perrot S, Leon T, Kaplan J, Petersel D, Ginovker A, Kramer E (2010) A patient survey of the impact of fibromyalgia and the journey to diagnosis. BMC Health Serv Res 10:102.

Cinar R, Gochuico BR, Iyer MR, Jourdan T, Yokoyama T, Park JK, Coffey NJ, Pri-Chen H, Szanda G, Liu Z, Mackie K, Gahl WA, Kunos G (2017) Cannabinoid $\mathrm{CB} 1$ receptor overactivity contributes to the pathogenesis of idiopathic pulmonary fibrosis. JCI Insight 2:e92281.

Colburn RW, Rickman AJ, DeLeo JA (1999) The effect of site and type of nerve injury on spinal glial activation and neuropathic pain behavior. Exp Neurol 157:289-304.

Cosenza-Nashat M, Zhao ML, Suh HS, Morgan J, Natividad R, Morgello S, Lee SC (2009) Expression of the translocator protein of $18 \mathrm{kDa}$ by microglia, macrophages and astrocytes based on immunohistochemical localization in abnormal human brain. Neuropathol Appl Neurobiol 35: 306-328.

Crook RJ, Dickson K, Hanlon RT, Walters ET (2014) Nociceptive sensitization reduces predation risk. Curr Biol 24:1121-1125.

Cropper HC, Johnson EM, Haight ES, Cordonnier SA, Chaney AM, Forman TE, Biswal A, Stevens MY, James ML, Tawfik VL (2019) Longitudinal translocator protein-18 $\mathrm{kDa}$-positron emission tomography imaging of peripheral and central myeloid cells in a mouse model of complex regional pain syndrome. Pain 160:2136-2148.

Cuadrado A, Rojo AI, Wells G, Hayes JD, Cousin SP, Rumsey WL, Attucks OC, Franklin S, Levonen AL, Kensler TW, Dinkova-Kostova AT (2019) Therapeutic targeting of the NRF2 and KEAP1 partnership in chronic diseases. Nat Rev Drug Discov 18:295-317.

Dahlhamer J (2018) Prevalence of chronic pain and high-impact chronic pain among adults - United States, 2016. MMWR Morb Mortal Wkly Rep 67:1001-1006. de Hair MJ, van de Sande MG, Ramwadhdoebe TH, Hansson M, Landewé R, van der Leij C, Maas M, Serre G, van Schaardenburg D, Klareskog L, Gerlag DM, van Baarsen LG, Tak PP (2014) Features of the synovium of individuals at risk of developing rheumatoid arthritis: implications for understanding preclinical rheumatoid arthritis. Arthritis Rheumatol 66:513-522.

Del Valle L, Schwartzman RJ, Alexander G (2009) Spinal cord histopathological alterations in a patient with longstanding complex regional pain syndrome. Brain Behav Immun 23:85-91.

DeMarco GJ, Nunamaker EA (2019) A review of the effects of pain and analgesia on immune system function and inflammation: relevance for preclinical studies. Comp Med 69:520-534.

Dodson M, de la Vega MR, Cholanians AB, Schmidlin CJ, Chapman E, Zhang DD (2018) Modulating NRF2 in disease: timing is everything. Annu Rev Pharmacol Toxicol 59:555-575.

Evans SF, Kwok YH, Solterbeck A, Liu J, Hutchinson MR, Hull ML, Rolan PE (2020) Toll-like receptor responsiveness of peripheral blood mononuclear cells in young women with dysmenorrhea. J Pain Res 13:503-516.

Fayaz A, Croft P, Langford RM, Donaldson LJ, Jones GT (2016) Prevalence of chronic pain in the UK: a systematic review and meta-analysis of population studies. BMJ Open 6:e010364.

Ferreira-Chamorro P, Redondo A, Riego G, Leánez S, Pol O (2018) Sulforaphane inhibited the nociceptive responses, anxiety- and depressive-like behaviors associated with neuropathic pain and improved the anti-allodynic effects of morphine in mice. Front Pharmacol 9:1332.

Finnerup N, Attal N, Haroutounian S, McNicol E, Baron R, Dworkin RH, Gilron I, Haanpää M, Hansson P, Jensen TS, Kamerman PR, Lund K, Moore A, Raja SN, Rice AS, Rowbotham M, Sena E, Siddall P, Smith BH, Wallace M (2015) Pharmacotherapy for neuropathic pain in adults: a systematic review and meta-analysis. Lancet Neurol 14:162-173.

Forsberg A, Lampa J, Estelius J, Cervenka S, Farde L, Halldin C, Lekander M, Olgart Höglund C, Kosek E (2019) Disease activity in rheumatoid arthritis is inversely related to cerebral TSPO binding assessed by $\left[{ }^{11} \mathrm{C}\right] \mathrm{PBR} 28$ positron emission tomography. J Neuroimmunol 334:577000.

Fox A, Kesingland A, Gentry C, McNair K, Patel S, Urban L, James I (2001) The role of central and peripheral Cannabinoid 1 receptors in the antihyperalgesic activity of cannabinoids in a model of neuropathic pain. Pain 92:91-100.

Garrison CJ, Dougherty PM, Kajander KC, Carlton SM (1991) Staining of glial fibrillary acidic protein (GFAP) in lumbar spinal cord increases following a sciatic nerve constriction injury. Brain Res 565:1-7.

Gasper DJ, Tejera MM, Suresh M (2014) CD4 T-cell memory generation and maintenance. Crit Rev Immunol 34:121-146.

Grace PM, Hutchinson MR, Bishop A, Somogyi AA, Mayrhofer G, Rolan PE (2011a) Adoptive transfer of peripheral immune cells potentiates allodynia in a graded chronic constriction injury model of neuropathic pain. Brain Behav Immun 25:503-513.

Grace PM, Rolan PE, Hutchinson MR (2011b) Peripheral immune contributions to the maintenance of central glial activation underlying neuropathic pain. Brain Behav Immun 25:1322-1332.

Grace PM, Hutchinson MR, Maier SF, Watkins LR (2014) Pathological pain and the neuroimmune interface. Nat Rev Immunol 14:217-231.

Grace PM, Gaudet AD, Staikopoulos V, Maier SF, Hutchinson MR, Salvemini D, Watkins LR (2016) Nitroxidative signaling mechanisms in pathological pain. Trends Neurosci 39:862-879.

Grace PM, Strand KA, Galer EL, Rice KC, Maier SF, Watkins LR (2018) Protraction of neuropathic pain by morphine is mediated by spinal damage associated molecular patterns (DAMPs) in male rats. Brain Behav Immun 72:45-50.

Griggs RB, Donahue RR, Morgenweck J, Grace PM, Sutton A, Watkins LR, Taylor BK (2015) Pioglitazone rapidly reduces neuropathic pain through astrocyte and nongenomic PPAR $\gamma$ mechanisms. Pain 156:469-482.

Guilarte TR (2019) TSPO in diverse CNS pathologies and psychiatric disease: a critical review and a way forward. Pharmacol Ther 194:44-58.

Habibalahi A, Moghari MD, Campbell JM, Anwer AG, Mahbub SB, Gosnell M, Saad S, Pollock C, Goldys EM (2020) Non-invasive real-time imaging of reactive oxygen species (ROS) using auto-fluorescence multispectral imaging technique: a novel tool for redox biology. Redox Biol 34:101561.

Hah JM, Cramer E, Hilmoe H, Schmidt P, McCue R, Trafton J, Clay D, Sharifzadeh Y, Ruchelli G, Goodman S, Huddleston J, Maloney WJ, Dirbas FM, Shrager J, Costouros JG, Curtin C, Mackey SC, Carroll I (2019) Factors associated with acute pain estimation, postoperative pain 
resolution, opioid cessation, and recovery: secondary analysis of a randomized clinical trial. JAMA Netw Open 2:e190168.

Haight ES, Forman TE, Cordonnier SA, James ML, Tawfik VL (2019) Microglial modulation as a target for chronic pain: from the bench to the bedside and back. Anesth Analg 128:737-746.

Hernstadt H, Wang S, Lim G, Mao J (2009) Spinal translocator protein (TSPO) modulates pain behavior in rats with CFA-induced monoarthritis. Brain Res 1286:42-52.

Holmdahl R, Rubin K, Klareskog L, Larsson E, Wigzell H (1986) Characterization of the antibody response in mice with type II collageninduced arthritis, using monoclonal anti-type II collagen antibodies. Arthritis Rheum 29:400-410.

International Association for the Study of Pain (2017) IASP terminology. International Association for the Study of Pain. Available at https://www. iasp-pain.org/terminology?navitemNumber $=576$.

Institute for Health Metrics and Evaluation (2017) Global burden of disease compare. Available at http://vizhub.healthdata.org/gbd-compare.

Inoue K, Tsuda M (2018) Microglia in neuropathic pain: cellular and molecular mechanisms and therapeutic potential. Nat Rev Neurosci 19:138-152.

Jacobson DL, Gange SJ, Rose NR, Graham NM (1997) Epidemiology and estimated population burden of selected autoimmune diseases in the United States. Clin Immunol Immunopathol 84:223-243.

James SL, Abate D, Abate KH, Abay SM, Abbafati C, Abbasi N, Abbastabar H, Abd-Allah F, Abdeka J, Abdelalim A, Abdollahpour I, Abdulkader RS, Abebe Z, Abera SF, Abil OZ, Abraha HN, Abu-Raddad LA, AbuRmeileh NM, Accrombessi MM, Acharya D, et al. (2018) Global, regional, and national incidence, prevalence, and years lived with disability for 354 diseases and injuries for 195 countries and territories, 1990-2017: a systematic analysis for the Global Burden of Disease Study 2017. Lancet 392:1789-1858.

Janes K, Neumann WL, Salvemini D (2012) Anti-superoxide and anti-peroxynitrite strategies in pain suppression. Biochim Biophys Acta 1822:815-821.

Ji RR, Chamessian A, Zhang YQ (2016) Pain regulation by non-neuronal cells and inflammation. Science 354:572-577.

Ji B, Maeda J, Sawada M, Ono M, Okauchi T, Inaji M, Zhang MR, Suzuki K, Ando K, Staufenbiel M, Trojanowski JQ, Lee VM, Higuchi M, Suhara T (2008) Imaging of peripheral benzodiazepine receptor expression as biomarkers of detrimental versus beneficial glial responses in mouse models of Alzheimer's and other CNS pathologies. J Neurosci 28:12255-12267.

Joffre J, Yeh CC, Wong E, Thete M, Xu F, Zlatanova I, Lloyd E, Kobzik L, Legrand M, Hellman J (2020) Activation of CB1R promotes lipopolysaccharide-induced IL-10 secretion by monocytic myeloid-derived suppressive cells and reduces acute inflammation and organ injury. J Immunol 204:3339-3350.

Jourdan T, Szanda G, Cinar R, Godlewski G, Holovac DJ, Park JK, Nicoloro S, Shen Y, Liu J, Rosenberg AZ, Liu Z, Czech MP, Kunos G (2017) Developmental role of macrophage cannabinoid-1 receptor signaling in type 2 diabetes. Diabetes 66:994-1007.

Kadetoff D, Lampa J, Westman M, Andersson M, Kosek E (2012) Evidence of central inflammation in fibromyalgia-increased cerebrospinal fluid interleukin-8 levels. J Neuroimmunol 242:33-38.

Kalliomäki J, Annas P, Huizar K, Clarke C, Zettergren A, Karlsten R, Segerdahl M (2013a) Evaluation of the analgesic efficacy and psychoactive effects of AZD1940, a novel peripherally acting cannabinoid agonist, in human capsaicin-induced pain and hyperalgesia. Clin Exp Pharmacol Physiol 40:212-218.

Kalliomäki J, Segerdahl M, Webster L, Reimfelt A, Huizar K, Annas P, Karlsten R, Quiding H (2013b) Evaluation of the analgesic efficacy of AZD1940, a novel cannabinoid agonist, on post-operative pain after lower third molar surgical removal. Scand J Pain 4:17-22.

Kato J, Agalave NM, Svensson CI (2016) Pattern recognition receptors in chronic pain: mechanisms and therapeutic implications. Eur J Pharmacol 788:261-273.

Kehlet H, Dahl JB (2003) Anaesthesia, surgery, and challenges in postoperative recovery. Lancet 362:1921-1928.

Khasabova IA, Khasabov SG, Olson JK, Uhelski ML, Kim AH, AlbinoRamírez AM, Wagner CL, Seybold VS, Simone DA (2019) Pioglitazone, a $\operatorname{PPAR} \gamma$ agonist, reduces cisplatin-evoked neuropathic pain by protecting against oxidative stress. Pain 160:688-701.

Kim D, You B, Jo EK, Han SK, Simon MI, Lee SJ (2010) NADPH oxidase 2derived reactive oxygen species in spinal cord microglia contribute to peripheral nerve injury-induced neuropathic pain. Proc Natl Acad Sci USA 107:14851-14856.

Kosek E, Altawil R, Kadetoff D, Finn A, Westman M, Le Maître E, Andersson M, Jensen-Urstad M, Lampa J (2015) Evidence of different mediators of central inflammation in dysfunctional and inflammatory pain-interleukin-8 in fibromyalgia and interleukin- $1 \beta$ in rheumatoid arthritis. J Neuroimmunol 280:49-55.

Kunos G, Osei-Hyiaman D, Bátkai S, Sharkey KA, Makriyannis A (2009) Should peripheral $\mathrm{CB}(1)$ cannabinoid receptors be selectively targeted for therapeutic gain? Trends Pharmacol Sci 30:1-7.

Kunos G, Tam J (2011) The case for peripheral $\mathrm{CB}_{1}$ receptor blockade in the treatment of visceral obesity and its cardiometabolic complications. $\mathrm{Br} \mathrm{J}$ Pharmacol 163:1423-1431.

Kwok YH, Hutchinson MR, Gentgall MG, Rolan PE (2012) Increased responsiveness of peripheral blood mononuclear cells to in vitro TLR 2, 4 and 7 ligand stimulation in chronic pain patients. PLoS ONE 7:e44232.

Lacagnina MJ, Watkins LR, Grace PM (2018) Toll-like receptors and their role in persistent pain. Pharmacol Ther 184:145-158.

Laumet G, Ma J, Robison AJ, Kumari S, Heijnen CJ, Kavelaars A (2019) T cells as an emerging target for chronic pain therapy. Front Mol Neurosci 12:216.

Li J, Ma J, Lacagnina MJ, Lorca S, Odem MA, Walters ET, Kavelaars A, Grace PM (2020) Oral dimethyl fumarate reduces peripheral neuropathic pain in rodents via NFE2L2 antioxidant signaling. Anesthesiology 132:343-356.

Lindh I, Snir O, Lönnblom E, Uysal H, Andersson I, Nandakumar KS, Vierboom M, 't Hart B, Malmström V, Holmdahl R (2014) Type II collagen antibody response is enriched in the synovial fluid of rheumatoid joints and directed to the same major epitopes as in collagen induced arthritis in primates and mice. Arthritis Res Ther 16:R143.

Lister KC, Bouchard SM, Markova T, Aternali A, Denecli P, Pimentel SD, Majeed M, Austin JS, Williams AC, Mogil JS (2020) Chronic pain produces hypervigilance to predator odor in mice. Curr Biol 30:R866-R867.

Little JW, Doyle T, Salvemini D (2012) Reactive nitroxidative species and nociceptive processing: determining the roles for nitric oxide, superoxide, and peroxynitrite in pain. Amino Acids 42:75-94.

Liu X, Liu H, Xu S, Tang Z, Xia W, Cheng Z, Li W, Jin Y (2016) Spinal translocator protein alleviates chronic neuropathic pain behavior and modulates spinal astrocyte-neuronal function in rats with L5 spinal nerve ligation model. Pain 157:103-116.

Loggia ML, Chonde DB, Akeju O, Arabasz G, Catana C, Edwards RR, Hill E, Hsu S, Izquierdo-Garcia D, Ji RR, Riley M, Wasan AD, Zürcher NR, Albrecht DS, Vangel MG, Rosen BR, Napadow V, Hooker JM (2015) Evidence for brain glial activation in chronic pain patients. Brain 138:604-615.

Loi F, Córdova LA, Pajarinen J, Lin T, Yao Z, Goodman SB (2016) Inflammation, fracture and bone repair. Bone 86:119-130.

Lois C, González I, Izquierdo-García D, Zürcher NR, Wilkens P, Loggia ML, Hooker JM, Rosas HD (2018) Neuroinflammation in Huntington's disease: new insights with ${ }^{11} \mathrm{C}$-PBR28 PET/MRI. ACS Chem Neurosci 9:2563-2571.

Lopes DM, Malek N, Edye M, Jager SB, McMurray S, McMahon SB, Denk F (2017) Sex differences in peripheral not central immune responses to pain-inducing injury. Sci Rep 7:16460.

Lu HC, Mackie K (2016) An introduction to the endogenous cannabinoid system. Biol Psychiatry 79:516-525.

Lyons DN, Zhang L, Danaher RJ, Miller CS, Westlund KN (2017) PPAR $\gamma$ agonists attenuate trigeminal neuropathic pain. Clin J Pain 33:1071-1080.

Mackie K (2005) Distribution of cannabinoid receptors in the central and peripheral nervous system. Handb Exp Pharmacol 168:299-325.

Mahbub SB, Guller A, Campbell JM, Anwer AG, Gosnell ME, Vesey G, Goldys EM (2019) Non-invasive monitoring of functional state of articular cartilage tissue with label-free unsupervised hyperspectral imaging. Sci Rep 9:4398

Malcangio M (2019) Role of the immune system in neuropathic pain. Scand J Pain 20:33-37.

Martin WJ, Patrick SL, Coffin PO, Tsou K, Walker JM (1995) An examination of the central sites of action of cannabinoid-induced antinociception in the rat. Life Sci 56:2103-2109.

McMahon SB, La Russa F, Bennett DL (2015) Crosstalk between the nociceptive and immune systems in host defence and disease. Nat Rev Neurosci 16:389-402. 
Mehta SP, MacDermid JC, Richardson J, MacIntyre NJ, Grewal R (2015) Baseline pain intensity is a predictor of chronic pain in individuals with distal radius fracture. J Orthop Sports Phys Ther 45:119-127.

Meller ST, Dykstra C, Grzybycki D, Murphy S, Gebhart GF (1994) The possible role of glia in nociceptive processing and hyperalgesia in the spinal cord of the rat. Neuropharmacology 33:1471-1478.

Meng ID, Johansen JP (2004) Antinociception and modulation of rostral ventromedial medulla neuronal activity by local microinfusion of a cannabinoid receptor agonist. Neuroscience 124:685-693.

Milligan AL, Szabo-Pardi TA, Burton MD (2020) Cannabinoid receptor type 1 and its role as an analgesic: an opioid alternative? J Dual Diagn 16:106119.

Nandakumar KS, Svensson L, Holmdahl R (2003) Collagen type II-specific monoclonal antibody-induced arthritis in mice: description of the disease and the influence of age, sex, and genes. Am J Pathol 163:1827-1837.

Narayanaswami V, Dahl K, Bernard-Gauthier V, Josephson L, Cumming P, Vasdev N (2018) Emerging PET radiotracers and targets for imaging of neuroinflammation in neurodegenerative diseases: outlook beyond TSPO. Mol Imaging 17:1536012118792317.

Navarrete F, García-Gutiérrez MS, Jurado-Barba R, Rubio G, Gasparyan A, Austrich-Olivares A, Manzanares J (2020) Endocannabinoid system components as potential biomarkers in psychiatry. Front Psychiatry 11:315.

Pacher P, Kunos G (2013) Modulating the endocannabinoid system in human health and disease: successes and failures. FEBS J 280:1918-1943.

Pacher P, Bátkai S, Kunos G (2006) The endocannabinoid system as an emerging target of pharmacotherapy. Pharmacol Rev 58:389-462.

Papadopoulos V, Baraldi M, Guilarte TR, Knudsen TB, Lacapère JJ, Lindemann P, Norenberg MD, Nutt D, Weizman A, Zhang MR, Gavish M (2006) Translocator protein (18kDa): new nomenclature for the peripheral-type benzodiazepine receptor based on its structure and molecular function. Trends Pharmacol Sci 27:402-409.

Parada CA, Yeh JJ, Reichling DB, Levine JD (2003) Transient attenuation of protein kinase Cepsilon can terminate a chronic hyperalgesic state in the rat. Neuroscience 120:219-226.

Patel UK, Anwar A, Saleem S, Malik P, Rasul B, Patel K, Yao R, Seshadri A, Yousufuddin M, Arumaithurai K (2019) Artificial intelligence as an emerging technology in the current care of neurological disorders. J Neurol. Advance online publication. Retrieved Aug 26, 2019.

Peirs C, Seal RP (2016) Neural circuits for pain: recent advances and current views. Science 354:578-584.

Peng J, Gu N, Zhou L, Eyo U, Murugan M, Gan WB, Wu LJ (2016) Microglia and monocytes synergistically promote the transition from acute to chronic pain after nerve injury. Nat Commun 7:12029.

Pernía-Andrade AJ, Kato A, Witschi R, Nyilas R, Katona I, Freund TF, Watanabe M, Filitz J, Koppert W, Schüttler J, Ji G, Neugebauer V, Marsicano G, Lutz B, Vanegas H, Zeilhofer HU (2009) Spinal endocannabinoids and $\mathrm{CB} 1$ receptors mediate $\mathrm{C}$-fiber-induced heterosynaptic pain sensitization. Science 325:760-764.

Pinho-Ribeiro FA, Verri WA, Chiu IM (2017) Nociceptor sensory neuronimmune interactions in pain and inflammation. Trends Immunol 38:5-19.

Próchnicki T, Mangan MS, Latz E (2016) Recent insights into the molecular mechanisms of the NLRP3 inflammasome activation. F1000Res 5:1469.

Qu L, Li Y, Pan X, Zhang P, LaMotte RH, Ma C (2012) Transient receptor potential canonical 3 (TRPC3) is required for IgG immune complexinduced excitation of the rat dorsal root ganglion neurons. J Neurosci 32:9554-9562.

Qu L, Zhang P, LaMotte RH, Ma C (2011) Neuronal Fc-gamma receptor I mediated excitatory effects of IgG immune complex on rat dorsal root ganglion neurons. Brain Behav Immun 25:1399-1407.

Reichling DB, Levine JD (2009) Critical role of nociceptor plasticity in chronic pain. Trends Neurosci 32:611-618.

Rudjito R, Agalave NM, Farinotti AB, Lundbäck P, Szabo-Pardi TA, Price TJ, Harris HE, Burton MD, Svensson CI (2020) Sex- and cell-dependent contribution of peripheral high mobility group box 1 and TLR4 in arthritisinduced pain. Pain. Advance online publication. Retrieved Sep 16, 2020.

Rupprecht R, Papadopoulos V, Rammes G, Baghai TC, Fan J, Akula N, Groyer G, Adams D, Schumacher M (2010) Translocator protein (18 $\mathrm{kDa})(\mathrm{TSPO})$ as a therapeutic target for neurological and psychiatric disorders. Nat Rev Drug Discov 9:971-988.

Salvemini D, Little JW, Doyle T, Neumann WL (2011) Roles of reactive oxygen and nitrogen species in pain. Free Radic Biol Med 51:951-966.
Sawicki CM, Kim JK, Weber MD, Jarrett BL, Godbout JP, Sheridan JF, Humeidan M (2018) Ropivacaine and bupivacaine prevent increased pain sensitivity without altering neuroimmune activation following repeated social defeat stress. Brain Behav Immun 69:113-123.

Seltzman HH, Shiner C, Hirt EE, Gilliam AF, Thomas BF, Maitra R, Snyder R, Black SL, Patel PR, Mulpuri Y, Spigelman I (2016) Peripherally selective cannabinoid 1 receptor (CB1R) agonists for the treatment of neuropathic pain. J Med Chem 59:7525-7543.

Sharma A, Rudra D (2018) Emerging functions of regulatory T cells in tissue homeostasis. Front Immunol 9:883.

Shi Y, Gelman BB, Lisinicchia JG, Tang SJ (2012) Chronic-pain-associated astrocytic reaction in the spinal cord dorsal horn of human immunodeficiency virus-infected patients. J Neurosci 32:10833-10840.

Sideris A, Piskoun B, Russo L, Norcini M, Blanck T, Recio-Pinto E (2016) Cannabinoid 1 receptor knockout mice display cold allodynia, but enhanced recovery from spared-nerve injury-induced mechanical hypersensitivity. Mol Pain 12:174480691664919.

Skaper SD, Di Marzo V (2012) Endocannabinoids in nervous system health and disease: the big picture in a nutshell. Philos Trans R Soc Lond B Biol Sci 367:3193-3200.

Sorge RE, LaCroix-Fralish ML, Tuttle AH, Sotocinal SG, Austin JS, Ritchie J, Chanda ML, Graham AC, Topham L, Beggs S, Salter MW, Mogil JS (2011) Spinal cord Toll-like receptor 4 mediates inflammatory and neuropathic hypersensitivity in male but not female mice. J Neurosci 31:15450-15454.

Sorge RE, Mapplebeck JC, Rosen S, Beggs S, Taves S, Alexander JK, Martin LJ, Austin JS, Sotocinal SG, Chen D, Yang M, Shi XQ, Huang H, Pillon PJ, Bilan PJ, Tu Y, Klip A, Ji RR, Zhang J, Salter MW, et al. (2015) Different immune cells mediate mechanical pain hypersensitivity in male and female mice. Nat Neurosci 18:1081-1083.

Staikopoulos V, Gosnell ME, Anwer AG, Mustafa S, Hutchinson MR, Goldys EM (2016) Hyperspectral imaging of endogenous fluorescent metabolic molecules to identify pain states in central nervous system tissue. Proceeding SPIE 10013, SPIE BioPhotonics Australasia, Adelaide, Australia.

Ständer S, Schmelz M, Metze D, Luger T, Rukwied R (2005) Distribution of cannabinoid receptor $1(\mathrm{CB} 1)$ and $2(\mathrm{CB} 2)$ on sensory nerve fibers and adnexal structures in human skin. J Dermatol Sci 38:177-188.

Su J, Gao T, Shi T, Xiang Q, Xu X, Wiesenfeld-Hallin Z, Hökfelt T, Svensson CI (2015) Phenotypic changes in dorsal root ganglion and spinal cord in the collagen antibody-induced arthritis mouse model. J Comp Neurol 523:1505-1528

Svensson M, Eriksson P, Persson JK, Molander C, Arvidsson J, Aldskogius H (1993) The response of central glia to peripheral nerve injury. Brain Res Bull 30:499-506.

Symons-Liguori A, Janes K, Neumann WL, Salvemini D (2016) The contribution of nitroxidative stress to pathophysiological pain and opioid analgesic failure. In: Redox-active therapeutics (Batinic-Haberle I, Reboucas, eds), pp 563-595. New York: Springer.

Tawfik VL, Huck NA, Baca QJ, Ganio E, Haight ES, Culos A, Ghaemi S, Phongpreecha T, Angst MS, Clark JD, Aghaeepour N, Gaudilliere B (2020a) Systematic immunophenotyping reveals sex-specific responses after painful injury in mice. Front Immunol 11:1652.

Tawfik VL, Quarta M, Paine P, Forman TE, Pajarinen J, Takemura Y, Goodman SB, Rando TA, Clark JD (2020b) Angiotensin receptor blockade mimics the effect of exercise on recovery after orthopaedic trauma by decreasing pain and improving muscle regeneration. J Physiol 598:317-329.

Taylor P, Manger B, Alvaro-Gracia J, Johnstone R, Gomez-Reino J, Eberhardt E, Wolfe F, Schwartzman S, Furfaro N, Kavanaugh A (2010) Patient perceptions concerning pain management in the treatment of rheumatoid arthritis. J Int Med Res 38:1213-1224.

Terato K, Hasty KA, Reife RA, Cremer MA, Kang AH, Stuart JM (1992) Induction of arthritis with monoclonal antibodies to collagen. J Immunol 148:2103-2108.

Torrado-Carvajal A, Toschi N, Albrecht DS, Chang K, Akeju O, Kim M, Edwards RR, Zhang Y, Hooker JM, Duggento A, Kalpathy-Cramer J, Napadow V, Loggia ML (2020) Thalamic neuroinflammation as a reproducible and discriminating signature for chronic low back pain. Pain, in press.

vom Steeg LG, Klein SL (2016) SeXX matters in infectious disease pathogenesis. PLoS Pathog 12:e1005374.

Wang C, Wang C (2017) Anti-nociceptive and anti-inflammatory actions of sulforaphane in chronic constriction injury-induced neuropathic pain mice. Inflammopharmacology 25:99-106. 
Wang L, Jiang X, Zheng Q, Jeon SM, Chen T, Liu Y, Kulaga H, Reed R, Dong X, Caterina MJ, Qu L (2019) Neuronal Fc $\gamma$ RI mediates acute and chronic joint pain. J Clin Invest 129:3754-3769.

Wang M, Wang X, Zhao L, Ma W, Rodriguez IR, Fariss RN, Wong WT (2014) Macroglia-microglia interactions via TSPO signaling regulates microglial activation in the mouse retina. J Neurosci 34:3793-3806.

Wardyn JD, Ponsford AH, Sanderson CM (2015) Dissecting molecular cross-talk between Nrf2 and NF- $\kappa$ B response pathways. Biochem Soc Trans 43:621-626.

Watkins LR, Martin D, Ulrich P, Tracey KJ, Maier SF (1997) Evidence for the involvement of spinal cord glia in subcutaneous formalin induced hyperalgesia in the rat. Pain 71:225-235.

Wei XH, Wei X, Chen FY, Zang Y, Xin WJ, Pang RP, Chen Y, Wang J, Li YY, Shen KF, Zhou LJ, Liu XG (2013) The upregulation of translocator protein $(18 \mathrm{kDa})$ promotes recovery from neuropathic pain in rats. J Neurosci 33:1540-1551.

Wohleb ES, Powell ND, Godbout JP, Sheridan JF (2013) Stress-induced recruitment of bone marrow-derived monocytes to the brain promotes anxiety-like behavior. J Neurosci 33:13820-13833.

Yang Y, Luo L, Cai X, Fang Y, Wang J, Chen G, Yang J, Zhou Q, Sun X, Cheng X, Yan H, Lu W, Hu C, Cao P (2018) Nrf2 inhibits oxaliplatininduced peripheral neuropathy via protection of mitochondrial function. Free Radic Biol Med 120:13-24

Zhang MA, Rego D, Moshkova M, Kebir H, Chruscinski A, Nguyen H, Akkermann R, Stanczyk FZ, Prat A, Steinman L, Dunn SE (2012) Peroxisome proliferator-activated receptor (PPAR) $\alpha$ and $-\gamma$ regulate IFN $\gamma$ and IL-17A production by human T cells in a sex-specific way. Proc Natl Acad Sci USA 109:9505-9510. 